\title{
Marxism's 'Communicative Crisis'? Mapping Debates over Leninist Print-Media Practices in the 20th Century
}

\author{
Herbert F. Pimlott Wilfrid Laurier University
}

\begin{abstract}
Résumé
En dépit du peu d'attention porté par les chercheurs à la «crise de communication » du marxisme, c'est un sujet d'inquiétude qui fut continuellement étudié, débattu et négocié au cours du XXe siècle par les chefs du parti, les intellectuels et les militants. Ces enjeux tournaient autour de trois questions : la première, le mode principal de communication écrite, le journal du parti; la seconde, la spécialisation de la production, en particulier le rôle des auteurs et journalistes; et la troisième, la recherche d'un style d'écriture et de rhétorique populaires, qui plairait au grand public. Cet essai retrace la « crise de communication » du marxisme au cours du XXe siècle en prenant, comme point de départ d'une analyse historique des échecs et des succès de la praxie politique marxiste, l'étude des points de rencontre clés entre les controverses concernant la bonne approche et les pratiques de communication écrite de cette praxie.
\end{abstract}

\begin{abstract}
Despite the scholarly neglect of Marxism's 'communicative crisis', it was a topic of concern that was addressed, debated and negotiated over by party leaders, intellectuals and activists on a continuous basis throughout the 20th century. These concerns revolved around three areas: first, the primary means of print communication, the party paper; second, the specialization of production, particularly around the role of writers and journalists; and third, the search for a popular rhetoric and writing style, which would appeal to the general public. This paper maps out the 'communicative crisis' of Marxism in the 20th century through an examination of key intersections of disputes over the correct approach to its practices of print communication, as a starting point for an historical analysis of the failures and successes of Marxist political praxis.
\end{abstract}

Newspapers, pamphlets and leaflets perform a necessary work of propaganda, agitation and organization. Not a single mass movement in any at all civilized country can dispense with a journalistic apparatus (Lenin, 1970: 120). 


\section{Mapping Debates over Leninist Print-Media Practices in the 20th Century}

\section{Introduction}

The history of radical working class movements of the 19th and 20th centuries in Europe and North America has always been intimately connected to print media and radical journalists and pamphleteers. ${ }^{1}$ Although extensive scholarly and activist literatures exist on the problems and potential, and the successes and failures of Marxist philosophy, ideology, political strategy and parties during the 20th century, one key area central to Marxist ${ }^{2}$ organization and political strategy that has been largely overlooked by scholars, despite its importance to the success of any political movement, is communication (Aune, 1994; Swartz, 1998; Williamson, 2002). Despite the scholarly neglect, however, the importance of communication was noted by leading Marxists, such as V.I. Lenin and Leon Trotsky.

This article maps out the 'communicative crisis' in 20th century Marxism as it was characterized implicitly and explicitly in debates and articles by party leaders, intellectuals and activists. These debates revolved around the 'correct' approach in each of three areas: first, the primary means of communication, the party paper; second, the role of professional journalists; and third, language and writing style. This paper will focus primarily upon the debates as played out in the UK during the 20th century. These debates over Marxist print-media practices, therefore, remain critical to thinking through the means of disseminating radical ideas to the public.

Although Communists and socialists have attempted to make use of the latest communication technologies since the Bolshevik revolution (e.g. Bolsheviks used film to reach workers and peasants in the 1920s; Marxist uses of the internet in the 1990s), print communication practices remain fundamental to a radical transformation of society for at least three important reasons (e.g. Atton, 2002; Downing, 1984; 2001; Mattelart and Siegelaub, 1979; 1983). First, the characteristics of print media, especially newspapers, pamphlets and periodicals, are superior to oral and broadcast media in developing sustained arguments over time that unravel ruling myths and reveal systemic realities, and promote a new vision of society and political praxis (e.g. Clark and Ivanic, 1997; Small, 1982). Second, print media have historically been more accessible to those with limited financial means and professional expertise than other media; print has traditionally had greater portability and flexibility than broadcast and digital technologies and print can be referred to, re-examined and studied at one's leisure more readily than broadcast media. Third, print media are an integral part of Marxist political organizations because publications disseminate ideas and publicize programs and actions: without print media, it would be virtually impossible to sustain the party and compete over ideas and for members.

${ }^{1}$ I would like to acknowledge that part of this research was made possible by a grant from Wilfrid Laurier University Operating Funds and the Social Science and Humanities Research Council (Canada) Institutional Grant.

${ }^{2}$ In this article, the terms 'Marxism' and 'Communism' are used interchangeably, referring primarily to political organizations that have, or have claimed to have, adopted the ideology and praxis of 'Marxism-Leninism'. 


\section{Marxism's 'Communicative Crisis'? Mapping Debates over Leninist Print-Media Practices in the 20th Century}

It is also important to note that virtually every Communist Part (CP), regardless of its size, resources and membership base, published three primary types of publications (Pimlott, 2000: 22-31). The first type was the party paper, which is similar to a newspaper in style, design and format. This is usually the one publication that remained the primary focus for party activists because it was the most public face of the party. ${ }^{3}$ The second was the "party review', for which formats varied, from mimeographed newsletters to magazines; it was addressed primarily to an internal party audience with in-depth coverage of party matters. The 'theoretical journal' was the third primary type; it was closer to an academic journal in format, audience and writing style, and was oriented towards intellectual discussions of Marxist theory and developing the party line on various issues.

\section{The Party Paper}

The Bolshevik or Leninist model of the press draws upon Lenin's ideas of (clandestine) political organization and strategy, and the experience of the party papers, Iskra and Pravda. From Bolshevism's beginnings in 1903, the party paper was seen as integral to Marxist political organization and strategy: Lenin's most famous pamphlet, What is to be Done?, is as much an argument for a 'revolutionary paper' as it is about anything else (Harman, 1984: 5). The party paper is central to the conception of the vanguard political party as a 'collective organizer.'

A newspaper is not only a collective propagandist and a collective agitator, it is also a collective organiser. In this respect it may be compared to the scaffolding erected round a building under construction... The organisation which forms [a]round this newspaper will be ready for everything, from upholding the banner, the prestige and the continuity of the party in periods of acute revolutionary depression to preparing for the nationwide armed insurrection (Lenin cited in Harman, 1984: 5).

It puts the paper at the core of its political strategy, where the paper's roles as (collective) agitator, propagandist, and organizer are at the centre of party efforts to disseminate its ideas, build the party, and, ultimately, organize the working class into a revolutionary movement with the vanguard party at its head (Bambery, 1996; Socialist Workers Party, 2002). This conception of the role of 'collective organizer' is equally that of 'collective communicator'; as it reaches out to internal and external audiences, the paper's primary function is not 'as adjunct to the building of an organization per se, but as an integral part in the constitution of that organisation' (Sparks, 1985: 142-143). Party and paper are inseparable.

This conception of the paper was codified into the Communist International's (CI) thesis on party organization, which includes the sub-section on the Communist paper: Section VI, 'On the Party Press.' It reiterates the need to constantly work 'to develop and improve'

${ }^{3}$ One exception was Marxism Today, the Communist Part of Great Britain's theoretical journal, during the 1980s (Pimlott, 2000). 
the paper, while recognizing the need to maintain its complete autonomy from capitalist institutions, such as advertisers; it also made it clear that all who worked on the paper, whether typesetters, secretaries or journalists, had to be party members (Communist International, 1979: 251, 252).

It should be noted here the differences between agitation and propaganda accentuate different audiences and their respective demands, and therefore, the need for different communicative practices. Agitators carry out party work primarily using the spoken word, albeit with supporting leaflets to hand out, to spread a few ideas amongst thousands of workers, with the paper providing the agitators with background material (information, commentary, analysis, news) (Downing, 2001: 68). Propaganda, on the other hand, is the long-term process of educating the more political and militant workers, and relies on the paper informing and sustaining them by providing the 'correct' interpretations of events, and drawing the links between seemingly discrete subjects, such as culture and the economy; the paper provides the 'ideological glue that will join up the disparate struggles of workers', which is meant to win them over to the party (Protz, 1979: 91; Downing, 2001: 68).

From this division between agitation and propaganda, both of which the party paper is meant to sustain, there is a fundamental division amongst Marxists over which audience the Communist press should target, that the lack of finances intensified (e.g. Allen, 1985; Hubert, 1988; Sparks, 1985). Should the paper address the most politicized workers (i.e. the vanguard) or a broader, but less politicized, general public? This dichotomy has never been fully resolved, despite the implications for editorial content, writing style and selection of journalists.

These questions affected the publications of the Communist Party of Great Britain (CPGB) from the party's inception in 1920, particularly during periods of social and industrial unrest. Workers' Weekly, which had replaced The Communist (1920-22) as the CPGB's paper, experienced rapid growth in circulation after Rajani Palme Dutt, a leading theoretician with close ties to the Comintern, took over as editor in 1923: increasing from 19,000 to 51,000 in just eight weeks (Macfarlane, 1966: 83). This growth in the circulation was a reflection of the CPGB's growing support amongst the working class amidst increasing industrial strife in the lead-up to the 1926 General Strike: Workers' Weekly circulation reached 80,000 by August 1926. However, one year later, its successor, Workers' ${ }^{2}$ ife ${ }^{4}$ dropped by 25 percent to 60,000; alongside a similar decline in workplace papers from 74 to 54, during the downturn in industrial struggles in the 18 months after the 1926 General Strike (Macfarlane, 1966: 178). As the party's fortunes declined, so did the paper's sales.

\footnotetext{
${ }^{4}$ A libel suit bankrupted Workers' Weekly in January 1927 (Macfarlane, 1966: 178).
} 


\section{Marxism's 'Communicative Crisis'? Mapping Debates over Leninist Print-Media Practices in the 20th Century}

The development of the 'Class-against-Class' policy or 'Third Period' of the Communist International, 1928-34, where socialists and social democrats were seen as class enemies and labelled 'social fascists,' saw a further decline in the sales of party literature. By July 1929, for example, only months before the Wall Street stock market crash and the start of the Great Depression, Workers' Life's weekly circulation had dropped to 27,500 (Macfarlane, 1966: 234). Despite the inauspicious situation of a deepening depression, mass unemployment, the CPGB's isolation from the Left, and the Trades Union Congress' loss of control of the Daily Herald (the labour movement's only daily paper), the party pessimists lost the argument against launching the CPGB's first daily newspaper (Richards, 1997: 2, 136-139; Rust, 1949: 10). Yet, the Daily Worker's role remained subject to dispute: debates raged over which events, issues and ideas to cover and how. Should the paper focus on a narrow area of political and industrial struggles, forming a communications link for party members and sympathetic trade unionists? Or should the paper aim at reaching a wider audience and, therefore, provide a variety of news besides political issues and party debates?

The debates sparked by these types of questions increased in intensity during periods of political crisis, which was exacerbated by and contributed to the decline in circulation and party membership (e.g. Allen, 1985; Macfarlane, 1966; Morgan, 1995; Sparks, 1985). For example, the Daily Worker's circulation rose as it began adopting a more 'popular' approach by the mid-1930s, with the shift to the CP's Popular Front policy. While both party and paper suffered as a result of the Nazi-Soviet, Non-Aggression Pact of 1939, after the German invasion of the USSR in 1941, their fortunes changed considerably: the Daily Worker relaunched in 1942, after having been proscribed for two years and its circulation increased to over 100,000 in the latter years of World War II, eventually peaking at 120,000 in 1949, shortly after the Cold War had begun in earnest (Morgan, 1995: 151, $152)$.

Disputes at The Daily Worker recurred over whether its direction should be more openly agitational or propagandist, which would help determine whether to include such elements of the capitalist press that appealed to the working class, such as sports and betting. Such discussions were never fully resolved and continued to exercise editorial staff, party leaders and the rank-and-file. In July 1956, one month after Nikita Khrushchev's 'secret speech,' an internal report pointed to two 'extreme' views of The Daily Worker. One wanted it to be a 'more pronouncedly party paper', reflecting the party's actions more and containing 'more fundamental theoretical articles,' and only within such a context could the language be simplified (Hutt, 1956: 1). The other, reflecting a majority opinion, wanted to remake the paper along the lines of the popular press, using the "most exciting and attractive items of news' and in an attractive layout to reach a broader audience; also, space for political items would be reduced, while retaining a 'sound core of Communist politics' 
(Hutt, 1956: 1). It was necessary, however, to try and achieve a balance between nonpolitical news and professional techniques, and retaining the Daily Worker's core message of class struggle when attempting to appeal to a broader public. 'We must simplify, lighten, humanise and picturise [sic]', editorial staff were urged, 'but in doing so must realise that we can only do so in relation to a given political content' (Hutt, 1956: 1). With the loss of one-quarter plus of party membership after 1956, reaching a broader public became critical to the long-term success of the Daily Worker.

In 1966, disputes over changing the Daily Worker's name again led to an intense debate amongst party supporters, including discussion about its role and writing style. George Allen Hutt, a leading newspaper designer of international repute, and an editor and journalist, who had worked on the paper almost continuously from its third month of publication and forgone a career with the mainstream media, brought up his retirement date to leave the Daily Worker before its name was changed (Hutt, 1966). The name change to the Morning Star was seen as a means to broaden its appeal, although circulation would continue to decline over the long term.

During the upturn in industrial militancy and social unrest in the UK in the early to mid1970s, Socialist Worker, the weekly paper of the British Trotskyist Socialist Workers' Party (SWP), which was the only party that had begun to rival the CPGB's dominant position on the far left, was subject to two intense debates over the paper's focus and audience, which led to internal splits and resignations of editorial staff (Allen, 1985). A former editor of Socialist Worker, Roger Protz, asked: 'Do you aim for a mass readership or do you concentrate on a smaller audience of more experienced people in the labour movement who demand more than just hand-me-down clichés?' (Protz, 1979: 92). Simple slogans, such as 'the-miners-are-fighting-for-all-of-us,' do not connect with the intended or target audience, but are connected to a particular view of the paper's audience (Protz, 1979: 92). This difference in views of the target audience is what led to the 1973-74 dispute at Socialist Worker between those who argued for writing for a broader, but less politicized audience and those who argued for writing for a narrower but more class conscious, politically-engaged readership. This latter audience demanded longer, more indepth articles, critical analysis and good writing than the expectations of a more general audience which would be closer to the shorter, less complex, more agitational articles. Protz argued that socialist papers have to concentrate on reaching more experienced and politicized workers and on providing material that can be used by activists when putting forward the party's position in the workplace (Protz, 1979: 92-93). 


\section{Marxism's 'Communicative Crisis'? \\ Mapping Debates over Leninist Print-Media Practices in the 20th Century}

\section{Professionals and Proletarians}

Parliamentarism is one form of activity, journalism is another. The content of both can be communist and it should be communist if those engaged in both spheres are real Communists, are real members of a proletarian party (Lenin, 1970: 120-121).

Unlike more recent ideas about the 'self-managed' model or the prefigurative politics of alternative media, the Bolshevik model of media benefits from clear power structures and a division of labour (Pimlott, 2000: 9-12). The paper is run according to the principles of 'democratic centralism' where party members, in theory, exercise control. The paper must not operate as if it were a separate, autonomous newspaper, as the capitalist press purports to do, because of the integral relation between the party's aims and the paper's form and content. However, relationships between party, paper and member-readers could become tense during periods of internal political crises, especially if communications from one part of the party, the dissenting group for example, was excluded from or marginalized in the party press: e.g. 1956 crisis (e.g. Isserman, 1987: 14-25; MacEwen, 1991: 179-193; Thompson, 1992: 104).

The choice of editor of the party paper is obviously a critical one because of the close relationship between party and paper in the Bolshevik model. The editor of the Daily Worker was always someone selected more for party-political nous than journalistic skill, and was invariably closely allied to the party leadership (Hutt, 1949: 1-2; Morgan, 1995: $144,150)$.

One of the first theorists of Communist press practices, Adalbert Fogarasi, argued against employing 'communist journalists' because having learned their professional newspaper techniques working for the capitalist press, they may inadvertently pass on 'capitalist ideology' through their writing, editing and other skills because such specialized techniques acquired from a capitalist institution correspond 'to the capitalist social order' and, therefore, reflect and communicate its values (Fogarasi, 1979: 152). ${ }^{5}$ Although Communist organizations in the West had to rely on 'technical experts' in journalism, just as the Soviets, for example, had to rely on US engineers to help with their hydro-electric projects, there was a concern that there was a greater chance of capitalist ideology being disseminated through Communist media than through industrial goods (e.g. Dutt, 1929; 1932; Fogarasi, 1979).

A leading exponent of this position was Rajani Palme Dutt, who was highly critical of professional journalists and argued against introducing their techniques into party

${ }^{5}$ This is a key critique in alternative media debates over whether adopting certain aspects of capitalist organization ultimately subverts radical aims or whether aspects of the capitalist marketplace can be used to disseminate radical ideas (e.g. Atton, 2002; Downing, 1984; 2001; Khiabany, 2000; Landry et al., 1985; Pimlott, 2000; 2004). 
publications (Macfarlane, 1966: 83; Dutt, 1932). As the Daily Worker began its third year with substantial debt and limited circulation, a public debate ensued between Dutt and the London Communist Print Group's (LCPG) Chairman (Rust, 1949: 18-25). The LCPG included party members who were journalists, sub-editors and printers in Fleet Street and offered free professional advice to the Daily Worker, despite criticisms by some CPGB officials (Chairman, 1932; Dutt, 1932). The LCPG's Chairman argued that the Daily Worker needed to adopt professional journalistic techniques to reproduce Fleet Street's efficiency and it could do so without capitalist ideological influence (Chairman, 1932: 249). The Chairman provided examples such as poor sub-editing skills which meant that minor news items were often filling small spaces where 'general news', more skillfully sub-edited, should have been (Chairman, 1932: 249). This riposte raised questions about the need for professional newspaper techniques to compete successfully for the allegiance of working class readers.

The debates around the Daily Worker between 1929 and 1932 pointed to a clear division between two fundamentally different understandings of the best way to reach the working class through the paper. On one side were those CPGB members who thought that adopting the writing styles, editorial content and layout of the leading tabloids, such as the Daily Express, would be bringing 'capitalist dope' into the workers' paper (e.g. Dutt, 1929; 1932). On the other side were those who felt that the Daily Worker should adopt those elements of working class culture that appealed to the readers and that they should not have to read about struggle and strife on every page (Chairman, 1932; Cohen, 1932). Even Harry Pollitt, General Secretary, 1929-56, argued for the inclusion of those aspects of mainstream tabloid content and practices in the Daily Worker, including the suggestion that they incorporate racing tips, for which the paper subsequently became famous after a successful run at picking winners (though complaints arose when 'Cayton' had a bad run) (Morgan, 1995: 154).

Fogarasi argued that the Communist press should be written by 'party members who can write' because they were Communists first and therefore unlikely to have been contaminated 'unknowingly' by the professional ideology of journalism (Fogarasi, 1979: 152-153). While he recognized the need for 'qualified party members [to] specialize in press activity', Fogarasi also stressed that all Communist editors and writers should also engage in party work outside their press activities to prevent reification and because professional techniques could have a negative impact on staff, removing them from engaging with crucial political issues as activists (Fogarasi, 1979: 152-153). Editors should have an in-depth political education, especially in economics, that would enable them 'to take a genuine Marxist position on all major questions'; which would ensure that editorial content would communicate more than simple generalities about 'capitalist exploitation, profiteering, speculation, etc.' (Fogarasi, 1979: 153). 


\section{Marxism's 'Communicative Crisis'? \\ Mapping Debates over Leninist Print-Media Practices in the 20th Century}

One attempt to redress the imbalance was to recruit 'worker correspondents' to try and ensure that party publications would 'speak' directly to the workers themselves because it was thought that workers would communicate more effectively with their own than party leaders or activists could, who may not have the same intimate knowledge of local grievances, political consciousness and language use; nevertheless, the party published handbooks offering basic writing tips (e.g. Dunne, 1928; Workers' Life, 1928). In the Civil War's aftermath, Trotsky highlighted the importance of worker correspondents' role 'in the raising of the cultural level' of their own class to better understand the need to defend their gains: 'Worker correspondents are the closest, most direct instruments of the newly awakened working class at the grass roots level' (Trotsky, 1973b: 162, 164). However, the Bolsheviks were less successful in reaching out to peasants during the same period because they apparently simply refused to read the Bolshevik press (Brooks, 2000: 7-9; Kenez, 1985: 47-48). It is unclear how successful the introduction of 'peasant correspondents' were in communicating party ideas and state policies to the rural population, which was an important objective because the peasantry constituted an overwhelming majority of the population and a potential threat to the Bolsheviks (Kenez, 1985: 49).

The CPGB also made effective use of worker correspondents during the 1920s. For example, over the first two years that Workers' Weekly was published, 1923-25, Harry Pollitt, organized a network of worker correspondents in factories and workshops across the UK. They provided information and stories for the Workers' Weekly and in turn helped to distribute it, doubling its circulation practically overnight from its precursor, The Communist (Morgan, 1993: 33). Its successor, the Daily Worker established a network of 300 worker correspondents in the factories and workshops across the UK during WWII, reporting on such things as production drives (Rust, 1949: 105). These networks were important sources of information about everyday struggles in local workplaces and neighbourhoods.

During the 1970s in the UK, with the combination of an upsurge in industrial militancy and a growth of interest in radical politics, the SWP attempted to draw upon its supporters and sympathizers as worker correspondents for Socialist Worker. It was thought that such contributors would be able to increase interest in the paper and, of course, the party, although it had limited success (Allen, 1985: 224, 228-229). Nonetheless, Socialist Worker retains pages of short news items about local disputes across different industries to help illustrate the widespread nature of workplace struggles.

On the one hand, the Communist movement tried to promote the use of workercorrespondents to avoid the potential harmful effects of capitalist ideology via professional 
journalism techniques and ensure that because worker-correspondents would know 'instinctually' what would interest other workers and write for this audience in a simple, 'proletarian' way, that they would have had more success in reaching out to them. On the other hand, professional journalists, who were CP members, were frequently treated with suspicion, and often found their suggestions ignored for fear of possible pernicious influence on party ideology. Indeed, these professionals, no matter how proletarian their origins, resolute their commitment and dedication to the party, and orthodox their ideological beliefs, were also overlooked for promotion to important positions such as editor or assistant editor of the daily newspaper. Instead, a committed party functionary or organizer would be promoted as part of the dominant fraction or tendency within the party.

One particularly interesting example of this is the case of the 'long-suffering' Daily Worker's chief subeditor, Hutt, the CPGB's 'most gifted and experienced journalist' (Morgan, 1995: 150). Hutt, who turned the Daily Worker into a disciplined, efficient newspaper along the Fleet Street model of professionalism and won four national design awards in the 1950s and 1960s, was passed over for both editor and deputy editor positions on at least two occasions in the 1940s (Hutt, 1949; MacEwen, 1991: 109-110; Morgan, 1995: 150). The second time it occurred, Hutt had to be talked out of resigning (Hutt, 1949). Hutt's letter to John Gollan, the CPGB leader, 1956-1975, after his retirement celebration is revealing:

... I appreciated your words of tribute... particularly your emphasis on the political, Marxist side of my character... [T]oo many people have too long regarded me as a 'technical' man - in the curiously pejorative sense in which the Party apparatus traditionally tends to use that word. (Hutt, 1966: 1).

Hutt had even pointed out several times that his 'technical' skills were as good as they were because of his belief in Marxism: 'The fact is that if I weren't a Marxist my technical achievements wouldn't be half what they are' (Hutt, 1966: 1).

At times, the contributions of professional journalists have been under the suspicion that their skills might undermine the substance of Communist propaganda because such techniques were utilized by the ideological state apparatuses of the capitalist system: i.e. the media. At particular historical conjunctures, the Communist parties adopted the approach where they would rely upon 'worker-correspondents' as their primary source of reports in their newspapers. This, unfortunately, does not always appear to have been as successful in practice as it was in theory: indeed, it was at times difficult enough to engage party leaders, let alone cadres, in writing because it was usually seen as a secondary activity to party-political and industrial work (e.g. Klugmann, 1960; 1973).

Despite the attempts by leading CP theorists and ideologues, such as Fogarasi and Dutt, 


\section{Marxism's 'Communicative Crisis'? Mapping Debates over Leninist Print-Media Practices in the 20th Century}

there really was no resolution to the tensions between 'journalists who are Communists' and 'Communists who can write' (Fogarasi, 1979: 152). The demonstration that such professionals as Hutt were often as committed to their (orthodox) Marxism as to their occupational skills did not seem to deter suspicions, no matter what. Clearly, one of the problems was not always so much who was doing the writing, but how their texts were written.

\section{Party Prose}

Even in the early part of the $20^{\text {th }}$ century, leading Communists, such as Lenin and Fogarasi, warned their followers against tendencies towards dogmatic assertions, jargon-laden rhetoric and sloganeering, advice which, at least by the apparent necessity for its continuous reiteration throughout the 20th century, appears to have frequently gone unheeded (Fogarasi, 1979; Lenin cited in Hobsbawm, 1984: 9). Indeed, Marxists have also usually denied the rhetorical nature and needs of their own proselytizing activities (Aune, 1994; Swartz, 1998). It must have been clear that there were problems with their rhetoric and writing style because as early as 1921 , leading Communists recognized the need 'to raise the level of intelligence and imagination of communist press writers', while others stressed the importance of writing clearly and 'concretely' in order to reach a working class audience (Fogarasi, 1979: 153; Beauchamp, 1945; Dunne, 1928; Hutt, 1956; Trotsky, 1973a; 1973b; Workers' Life, 1928).

The inability of Marxist publications to attract readers outside of the initiated, James Arnt Aune suggests, is partly a result of the 'Marxist view of language, ideology, and value in audience-centered terms' (Aune, 1994: 24). A product of Enlightenment thinking in its overt belief in the ultimate triumph of reason over superstition, Marxist belief in transparency in language is related to its political praxis: Marxism is a 'science' which 'unmasks' power and makes social relations 'transparent' and therefore it does not need 'artifice' (i.e. rhetoric) (Aune, 1994: 34). It originated with The Communist Manifesto, Aune suggests, where metaphors of 'secrecy/openness' and 'opacity/transparency' organized 'arguments about political strategy', that radicalism had to be 'manifest', and that it would lay 'bare [the] social reality' of capitalism (Aune, 1994: 34). This translated into a belief that it is only necessary to show the working class the need for Marxism because Marxists have assumed 'the need for revolution' to be 'self-evident, without considering that people might need to be persuaded to that belief' (Aune, 1994: 14). However, even if Marx and other 19th century socialists believed this, it did not mean they ignored the importance of being persuasive (e.g. McLeish, 1997; Osborne, 1998; Yelland, 1997).

The focus of Marxism on 'revealing' is evident in the way the CPs were convinced that they were the only bearers of 'objective truth' of the 'material reality' of life in the 
capitalist system: 'The communist press stands on the only ground prescribed by its ideological position: the communist press is the historical agent of truth,' although the 'criteria of truth do not lie in individual facts but in the totality, of communist theory and praxis'; truth is a means to 'awakening communist consciousness' (Fogarasi, 1979: 151). Nevertheless, the end result was to place considerable emphasis on the ability of the working class to recognize its own material interests 'as soon as the subjective conditions (ideological maturity) are present,' which would help explain the focus on 'false consciousness' as an explanation for the failure of CPs to achieve greater support amongst the working class (Fogarasi, 1979: 152).

The problem of identifying their audience(s) and addressing them in an appropriate and persuasive manner was a major stumbling block for the Marxist Left. Fogarasi warned against the 'doctrinaire conception' that the 'communist press is written only for communist[s]'; the different tasks of agitation and of propaganda meant distinguishing between external and internal publics (Fogarasi, 1979: 152). Yet, that most Communist publications were written by and for Communists is obvious in their choice of concepts, such as 'proletariat' and 'imperialism'. It is this 'strangeness' of Marxist discourse, in terms of everyday language, that distances its potential audiences: its terms do not appeal to those they are ostensibly meant to address. Many of these terms, which had a particular resonance in their original language, such as Russian, were simply translated in a slavish imitation of the Soviet or Chinese CPs (e.g. Burgchardt, 1980; Chairman, 1932; Protz, 1979; Williamson, 2002).

Criticisms of 'translationese' have been made at various times by Communist journalists and activists (Williamson, 2002). The LCPG, for example, made it clear that they were not against 'difficult words' but against the 'semi-technical phraseology acquired from the reading of bad translations from the Russian and German' (Chairman, 1932: 249). 'Third Period' language lacked appeal even in the early 1930s, at a time when Communist pamphleteers' expressed their '[a]cceptance of violence' through martial language and 'images and metaphors of natural violence - floods, storms, hurricanes, and volcanoes,' which appeared to alienate non-Communists (Burgchardt, 1980: 379). This criticism is one possible explanation for the limited appeal of the CP during the 'Third Period,' which was a time when party memberships declined dramatically: e.g. CPGB membership dropped from its October 1926 peak of 10,730 to 2,555 members in 1930, part-way into the "class against class' line (Thompson, 1992: 218).

However, by the mid-1930s, with fascism gaining strength in Europe, leading Communists recognized that finding 'a common language with the broadest masses', was not only necessary for 'struggling against the class enemy', but also for 'overcoming the isolation of the revolutionary vanguard from the masses': an integral part of popular front strategy 


\section{Marxism's 'Communicative Crisis'? Mapping Debates over Leninist Print-Media Practices in the 20th Century}

(Dimitrov, 1935). The shift in approach, where the common usage of words was adopted, did help increase the CP's appeal to a broader public. The Communist Party of the United States of America's (CPUSA) Popular Front pamphlets were more acceptable to non-party people because they no longer targeted other working class or socialist organizations as 'class traitors' or 'social fascists' but as potential allies, and in doing so sought to appeal to a broader audience by dispensing with some of their more apocalyptic and violent rhetoric (Burgchardt, 1980). Communist fortunes changed with the change in policy and their language use: by 1938, peak year for the popular front, CPGB membership reached its greatest strength yet at 15,500 and was still rising (Thompson, 1992: 62).

In the 1980 s, attempts to reach out to new social movements frequently did not work because the militaristic language and 'macho' style of classical Marxism failed to appeal to many outside the Marxist Left, such as those involved in the women's or peace movements (e.g. Brunt, 1987; Cockburn, 1988). Nonetheless, an argument can be made for the appropriateness of particular word choices, violent or militaristic metaphors and even sloganeering, particularly during times of political crisis and impending (civil) war. For example, Lenin has argued for using violent language and militaristic metaphors as a means to break the complacency of public discourse and to force readers and listeners to rethink their acceptance of the status quo, such as the rule of the Tsars in Russia (Weinroth, 1996: 112).

Some terms, however, may have been too sacrosanct in the party's ideology to be changed. For example, at the American Writers' Congress organized by the CPUSA in 1935, Kenneth Burke suggested that the term 'worker' or 'working class' should be replaced with 'people' to try and appeal more successfully to ordinary Americans (Burke, 1935). Such a term, Burke argued, was necessary because it builds upon the idea of incorporating other classes into a broad alliance with the 'working class,' which would be a necessary condition as capitalism underwent its crises and class conflict increased; the other option was one which would lead to a marginalized, isolated proletariat cut off from potential allies (Burke, 1935). He was quickly dismissed by all the other speakers at the Congress. During the new conservative hegemony of the late 1980s, a similar suggestion was made to the US Left to use the word 'people' instead of 'workers' to try and address a broader public (Kazin, 1988). The choice of either term, 'working class' or 'people,' reflects differences in target audiences and the paper's role.

It was not only that some of the terms and expressions were being translated from one language into another, but that the younger generation of potential activists and supporters did not have the same experience from which such language was drawn and within which its context resonated with an earlier generation of readers and listeners. Leon Trotsky (1923), for example, criticized the new generation of 'writers and propagandists' in the 
1920s for not being able to write in a manner that was comprehensible to ordinary Russians, because these young communicators drew upon 'ready formulas, phrases, expressions, and words' of the Old Bolsheviks, for whom this language had meaning because it came out of their experience. However, for the younger generation, these phrases 'remain almost empty sounds' (Trotsky, 1973a: 128). The danger was that the content and form of agitational material was outside the language and experience of both workers and peasants. These propagandists were contributing to the "construction of an almost arbitrary party language, inaccessible to almost nine-tenths not only of the peasants but even of the workers' (Trotsky, 1973a: 128). The distance between rhetoric and reality in the USSR was a common criticism in the West, but it was also a lesson that Soviet citizens learned in reading the message 'between the lines.'

From at least the 1920s, concerns were expressed over jargon and slogans standing in for 'a genuine Marxist standpoint and knowledge' (Fogarasi, 1979: 152). The problem was not just the choice of language or writing style but that the kind of writing that the Daily Worker was producing, according to the Chairman of the LCPG, was not properly supported or logically persuasive. 'Pick up any issue of the Daily Worker and you find merely mechanical statements, unsupported by evidence and improperly worked out' (Chairman, 1932: 250). They argued for 'abolishing the jargon which renders the Daily Worker almost incomprehensible to the reader who has not "learned the language", because it assumes 'too much knowledge on the part of the reader' and is an indication of the writer's lack of technical ability and knowledge (Chairman, 1932: 249).

There was a recognition for different levels of writing depending upon the topic's complexity. 'Lately the demand is often heard that writing be such that all readers can understand everything which is not identical with the demand for clearer, simpler, more understandable writing' (Fogarasi, 1979: 152). An accessible style was dependent upon the complexity of the subject matter itself: Marx's Capital could not have been made more accessible in the vernacular (Trotsky, 1973b: 168-169).

This point has been reiterated at different times during the 20th century (e.g. Fogarasi, 1979; Lenin, 1970). The continual stress on the need to write simply, clearly and 'concretely' was advice that was continually reiterated for the benefit of all. Not that writing simply was necessarily easy: 'What the Daily Worker should learn, and what the workers appreciate, is plain English. And, believe me, the writing of plain English requires stern training' (Chairman, 1932: 249, original emphasis). Trotsky also emphasized this point: 


\section{Marxism's 'Communicative Crisis'? Mapping Debates over Leninist Print-Media Practices in the 20th Century}

It is not such a simple thing at all to write simply. 'Simplicity' alone is totally inadequate. One needs ability; one needs proficiency. It is necessary to cultivate your manner of exposition, your style. This is work; this is a task; this means studying (Trotsky, 1973b: 165).

Similar advice to eschew jargon and write simply was given to both worker correspondents and party journalists. During its first years, the Daily Worker was seen as essentially - and not flatteringly - by many of its own journalists as a 'propaganda sheet' (Morgan 1995: 149). Despite the admonitions from people like Dutt, who saw any form of bourgeois journalism as weakening the Communist politics and values of the paper, the Daily Worker followed a gradual, but consistent lightening of its tone during the 1930s (Morgan 1995: 146-147).

However, it was often during times of change that the daily or weekly paper became the focus for debate about how the press should address their potential audience(s) and who they should target. For example, after the Morning Star's circulation began to decline steadily after 1974, CPGB members began to raise questions about its content, format, layout and writing style. During the 1977 National Congress, the leadership was forced to accept a motion criticizing the Morning Star, one of only two ever defeats of party leaders in the CPGB's history to that date, and established a committee to investigate (Andrews, 1995; Morgan, 1995). The committee's 1978 report criticized its writing style for a prosaic and boring rendition of news, commentary, culture and sports (Sub-Committee on the Morning Star, 1978).

With communication a key part of building a revolutionary party and movement, it should be of little surprise that the problems with Communist journalism's rhetoric and writing style became part of the crisis of 1956, as it had allowed the Communists to shut out uncomfortable realities and ignore problems with party organization and policies. Communists complained that the party used language in a 'ritualistic, pseudoscientific style of writing and speaking,' which could be used as a 'shield against emotion and uncertainty', by pigeonholing anything seen as 'threatening' so that it could be ignored (Isserman, 1987: 18). Chick Mason, contrasting the post-1945 isolation of the party with its position during the Popular Front era, pointed out that in the late 1930s the CPUSA had 'begun to speak a language that could be understood, at least by us [and] that could almost be understood by millions of Americans' (cited in Isserman, 1987: 21). Another critic, Jessica Mitford, composed a guide to Marxist-Leninist language usage, 'Lifeitselfmanship,' in which she parodied the CPUSA's use of jargon (it actually received favourable mention in the party press) (Mitford, 1977: 269-274, 323-333).

Despite important, useful and practical suggestions on their own communicative practices, it appears that during periods of crisis, such as 1928-34 and 1956, Marxists frequently 
ignored these criticisms and, instead, substituted an appeal to Marxist-Leninist ideology through the appropriate phraseology, the 'correct' interpretation of events, or 'the party line' as solutions to their communicative problems. This criticism of the language and writing style is not necessarily one of tactics or objectives of the parties, nor the validity of particular ideologies or political strategies. It is, however, an ongoing criticism of a failure to address and resolve communicating effectively with the intended audience.

\section{Conclusion}

This essay mapped out a selection of key debates in the 'communicative crisis' of Marxism during the 20th century, primarily from the UK, which highlight ongoing disputes over the role and target audience(s) of the party paper, whether professionals or proletarians should write for it, and the paper's language and writing style. It reiterated the importance of print-media practices in their constitutive role in the Communist party and in the Leninist conceptualization of the party paper as the 'collective organizer' of the working class. This mapping exercise also highlights an overlap between debates about paper, professionalism and prose, and periods of political-ideological crisis or industrial unrest. Although this essay does not attempt to offer any assessment of the direct impact of print communicative practices on the political effectiveness and success or failure of Marxist organizations beyond some circulation figures, it does suggest that there is a need to recognize their importance in the success or failure of Marxist ideas and political organizations. Leading Communists, such as Fogarasi, Trotsky and Dimitrov, however, have recognized the importance of these practices when, for example, they have exhorted their comrades to write in a more accessible style or to adopt a 'common language' to reach the working class. While debates over adopting aspects of capitalist journalism remain fundamentally unresolved, it does suggest that the general trend of increased circulation and influence was in part at least a result of a turn to a more professional outlook and popular style, though professionals, such as Hutt, could be as orthodox in their beliefs as they were professional in their work (e.g. Hubert, 1988; MacEwen, 1991: 186-187; Morgan, 1995: 150-151). 


\section{REFERENCES}

Allen, P. 1985. "Socialist Worker: Paper With a Purpose." Media, Culture and Society, Vol.7, pp. 205-232.

Andrews, G. 1995. "“Young Turks and Old Guard': Intellectuals and the Communist Party Leadership in the 1970s." In Opening the Books: Essays on the Social and Cultural History of the British Communist Party. G. Andrews, N. Fishman and K. Morgan (eds.). London: Pluto, pp. 225-250.

Atton, C. 2002. Alternative Media. London: Sage.

Aune, J. A. 1994. Rhetoric and Marxism. Boulder: Westview Press.

Bambery, C. 1996. The Case for the Socialist Newspaper. London: SWP.

Beauchamp, K. (ed.). 1945. Plan Your Publicity: A Handbook for Communist Candidates and Branch Officers. London: CPGB.

Brooks, J. 2000. Thank You, Comrade Stalin! Soviet Public Culture from Revolution to Cold War. Princeton, NJ: Princeton University Press.

Brunt, R. 1987. “The Left's Hallelujah Chorus.” Marxism Today, Vol.31, No.12, pp. 32-35.

Burgchardt, C. 1980. "Two Faces of American Communism: Pamphlet Rhetoric of the Third Period and the Popular Front." Quarterly Journal of Speech, Vol.66, pp. 375-391.

Burke, K. 1935. "Revolutionary Symbolism in America." In American Writers' Congress. H. Hart (ed.). New York: International Publishers, pp. 87-94.

Chairman, London Communist Print Group. 1932. “A Popular Workers’ Newspaper.” The Communist Review, Vol.4, No.5, pp. 245-250.

Clark, R. \& R. Ivanic. 1997. The Politics of Writing. London and New York: Routledge.

Cockburn, C. 1988. "Macho Men of the Left." Marxism Today, Vol.32, No.4, pp. 18-23.

Cohen, J. 1932. "Critical Thoughts on our Agitation and Propaganda." The Communist Review, Vol.4, No.6, pp. 292-297. 
Communist International. 1979. "Thesis on the Organization and Structure of the Communist Parties." In Communication and Class Struggle: Volume 1: Capitalism, Imperialism. A. Mattelart and S. Siegelaub (eds.). New York: IMMRC/International General, pp. 149-152. First published in 1921.

Dimitrov, G. 1935. "The Fascist Offensive and the Tasks of the Communist International in the Struggle of the Working Class Against Fascism." Speech at the VII World Congress of the Communist International, 2 August 1935.

(<http://csf.colorado.edu/psn/marx/Other/Dimitrov/1935-rep.htm> accessed 20 January 2004).

Downing, J. 1984. Radical Media. Boston: South End Press.

Downing, J. 2001. Radical Media: Rebellious Communication and Social Movements. With T.V. Ford, G. Gil and L. Stein. Thousand Oaks: Sage. Revised edition.

Dunne, W. F. 1928. Worker Correspondents. Chicago: CPUSA.

Dutt, R. P. 1932. "Bourgeois Journalism and Our Press.” The Communist Review, Vol.4, No.7, pp. 325-331.

Dutt, R. P. 1929. “Towards the Workers' Daily.” The Communist Review, Vol.1, No.12, pp. 628-643.

Fogarasi, A. 1979. "The Tasks of the Communist Press." In Communication and Class Struggle: Volume 1: Capitalism, Imperialism. A. Mattelart and S. Siegelaub (eds.). New York: IMMRC/International General, pp. 149-152. First published in 1921.

Harman, C. 1984. "The Revolutionary Press.” International Socialism, Series 2, No. 24, pp. 3-44.

Hobsbawm, E. 1984. “Labour: Rump or Rebirth?” Marxism Today, Vol.28, No.3, pp 8-12.

Hubert, P. J. 1988. On Party and Propaganda in the Newspapers of the Left. Unpublished Ph.D. Dissertation. University of Leeds.

Hudson, Jr., H. D. 2004. "Bridging the Russian Cultural Gap: Language and Culture Wars in the Creation of a Soviet Peasant Press." American Journalism, Vol.21, No.1, pp. 13-36. 


\section{Marxism's 'Communicative Crisis'? Mapping Debates over Leninist Print-Media Practices in the 20th Century}

Hutt, G. A. 1966. Letter to John Gollan. Typescript, 5 June. George Allen Hutt Papers, Cambridge University Library.

Hutt, G. A. 1956. “The Daily Worker: Its Policy and Content”. Typescript memo, July. George Allen Hutt Papers, Cambridge University Library.

Hutt, G. A. 1949. Resignation Letter [not submitted]. Typescript, 14 February. George Allen Hutt Papers, Cambridge University Library.

Isserman, M. 1987. If I Had a Hammer: The Death of the Old Left and the Birth of the New Left. New York: Basic Books.

Kazin, M. 1988. "A People Not a Class: Rethinking the Political Language of the Modern US Labor Movement.” In The Year Left: Volume 3; Reshaping the US Left. M. Davis and M. Sprinker (eds.). New York: Verso, pp. 257-286.

Kenez, P. 1985. The Birth of the Propaganda State: Soviet Methods of Mass Mobilization, 1971-1929. Cambridge: Cambridge University Press.

Khiabany, G. 2000. "Red Pepper: A New Model for the Alternative Press?" Media, Culture and Society, Vol.22, pp. 447-464.

Klugmann, J. 1960. Proposals for the Development of Marxism Today. Marxism Today Editorial Board Minutes. Communist Party of Great Britain Archives.

Klugmann, J. 1973. Marxism Today: Background Notes. Political Committee Minutes, 12 June. Communist Party of Great Britain Archives.

Landry, C., Morley, D. Southwood, R. \& P. Wright. 1985. What a Way to Run a Railroad: An Analysis of Radical Failure. London: Comedia.

Lenin, V. I. 1970. 'Left-Wing' Communism, An Infantile Disorder. Peking: Foreign Languages Press. First published in 1920.

MacEwen, M. 1991. The Greening of a Red. London: Pluto Press.

Macfarlane, L. J. 1966. The British Communist Party: Its Origin and Development Until 1929. London: MacGibbon and Kee.

Mattelart, A. \& S. Siegelaub (eds.). 1979. Communication and Class Struggle: Volume 1, Capitalism, Imperialism. New York: IMMRC/International General. 
Mattelart, A. \& S. Siegelaub (eds.). 1983. Communication and Class Struggle: Volume 2, Liberation, Socialism. New York: IMMRC/International General.

McLeish, A. 1997. "The Rhetoric of the Communist Manifesto." Studies in Marxism, No.4, pp. 59-78.

Mitford, J. 1977. A Fine Old Conflict. New York: Alfred A. Knopf.

Morgan, K. 1995. "The Communist Party and the Daily Worker 1930-56." In Opening the Books: Essays on the Social and Cultural History of the British Communist Party. G. Andrews, N. Fishman and K. Morgan (eds.). London: Pluto, pp. 142-159.

Morgan, K. 1993. Harry Pollitt. Manchester and New York: Manchester University Press.

Osborne, P. 1998. "Remember the Future? The Communist Manifesto as Historical and Cultural Form." Socialist Register 1998, pp. 190-204.

Pimlott, H. 2004. "From the Margins to the Mainstream: The Promotion and Distribution of Marxism Today." Journalism: Theory, Practice and Criticism, Vol.5, No.2, pp. 203-226.

Pimlott, H. 2000. From the Margins to the Mainstream: A Case Study of the Transformation of Marxism Today. Unpublished Ph.D. Dissertation. University of London.

Protz, R. 1979. "Their Papers and Ours." In Media, Politics and Culture: A Socialist View. C. Gardner (ed.). Basingstoke: Macmillan, pp. 88-94.

Richards, H. 1997. The Bloody Circus: The Daily Herald and the Left. London: Pluto Press.

Rust, W. 1949. The Story of the Daily Worker. Edited and completed by Allen Hutt. London: People's Press Printing Society.

Small, C. 1982. The Printed Word: An Instrument of Popularity. Aberdeen: Aberdeen University Press.

Socialist Workers Party (ed.). 2002. Socialist Worker: Fighting to the Change the World. London: SWP. 


\section{Mapping Debates over Leninist Print-Media Practices in the 20th Century}

Sparks, C. 1985. "The Working-Class Press: Radical and Revolutionary Alternatives." Media, Culture and Society, Vol. 7, pp. 133-146.

Sub-Committee on the Morning Star, Executive Committee. 1978. Report on the Morning Star. London: CPGB.

Swartz, O. 1998. Language and Socialism. Aldershot: Ashgate Publishing.

Thompson, W. 1992. The Good Old Cause: British Communism, 1920-1991. London: Pluto.

Trotsky, L. 1973a. “The Newspaper and Its Readers." In Problems of Everyday Life, New York: Pathfinder Press, pp. 120-128. Translated by I. Fraser. First published in 1923.

Trotsky, L. 1973b. "The Cultural Role of the Worker Correspondent." In Problems of Everyday Life, New York: Pathfinder Press, pp162-183. Translated by M. Vogt. First published in 1924.

Weinroth, M. 1996. Reclaiming William Morris: Englishness, Sublimity and the Rhetoric of Dissent. Montreal and Kingston: McGill-Queen's University Press.

Williamson, O. 2002. Contemporary American Orthodox Marxist Rhetoric. (<http://utminers.utep.edu/omwilliamson/thesisthesis.doc> Accessed 21 January 2004.).

Workers' Life. 1928. The Worker Correspondent. London: CPGB.

Yelland, C. 1997. "The Communist Manifesto: A Linguistic Approach.” Studies in Marxism, No.4, pp. 47-58. 